\title{
VISUMINĖ SVEIKATA IR DARNA ŠIAURIETIŠKOS KULTŪROS KONSTRUKTO STRUKTŪROJE
}

\author{
Birutė Strukčinskiene் $\dot{1}^{1}$, Sigitas Griškonis ${ }^{1,2}$ \\ ${ }^{1}$ Klaipedos universiteto Sveikatos mokslu fakultetas, ${ }^{2}$ Klaipèdos universitetine ligonine
}

Raktažodžiai: visuminè sveikata, darna, kultūros konstruktas, Šiaurès šalių konceptas, Suomija, sisu fenomenas.

\section{Santrauka}

Pastaruoju metu Lietuva ir kitos Baltijos šalys priskiriamos Šiaurès šalių regionui. Tad nestebina siekis atsigręžti i artimiausių kaimynių ir tautų patirtị, tradicijas, nuostatas ir gyvenimo stilių, ieškant darnos sveikatos-gamtos-žmogaus dimensijose ir pritaikant tautinio tapatumo konstruktą mūsiškame kontekste. Straipsnyje aptariami suomiško kultūrinio tapatumo komponentai, analizuojamas šiaurietiškas kultūrinis konstruktas sisu, jo sąlytis su visumine sveikata ir harmonija, diskutuojama, kaip ugdomas sisu.

Sisu - tai suomių kultūros fenomenas, originalios gyvensenos pavyzdys, tradicinès ideologijos konceptas. Tai šiaurietiškas kultūrinis konstruktas, tautinio tapatumo išraiška, savita ilgaamžè tradicinè ideologija, unikalus gyvenimo būdas. Sisu - tai nuoseklus ir drąsus požiūris ị iššūkius, kurie iš pirmo žvilgsnio atrodo viršijantys žmogaus galias ir pajègumus. Tai energijos rezervas, skirtas iššūkiams nugalèti, savita drąsa ir atkaklumas, papildomų jëgų sutelkimas ir pasireiškimas, siekiant užsibrèžto tikslo. Pastangos sukaupti papildomą atsarginę energiją, išsiugdyti, surasti savo sisu ir taip sustiprinti savo fizinę ir psichikos sveikatą bei harmonizuoti visuminę žmogaus sveikatą - siektinas iššūkis individui ir visuomenei. Konstruktyvaus sisu ugdymas padeda didinti atsparumą, atkaklumą, ištvermę bei stiprinti visapusišką sveikatą ir darną. Sisu ugdymui svarbūs komponentai yra: sąveika su gamta, gamtos bei miško terapija, pozityvumas, poilsis, atsiribojimas ir atsitraukimas, naštos sumažinimas (fragmentizacija), išèjimas iš komforto zonos (maži iššūkiai), perdavimas ir plitimas, fizinè veikla bei fizinis aktyvumas, apdovanojimas, ịveikus užduotị.

\section{Ivadas}

Interdisciplininiu požiūriu aktualūs fizinès, psichinès, dvasinès, emocinès ir apskritai visuminès sveikatos kon- tekstai, interakcija su gyvensena, gyvenimo ideologija bei sinergija su gerove ir gyvenimo kokybe skatina ieškoti sąlyčio su ịvairiu kultūriniu konstruktu. Visuminès sveikatos ir vidinès darnos, harmonijos, gerovès suvokimu bei sąveika skirtingose kultūrose jau daugelį metų domèjosi įvairių tautų mokslininkai ir tyrejai. Lietuvoje buvo akcentuojamas Vydūno visuminis holistinis požiūris ị sveikatą, skatinant visuomenę eiti Vydūno keliu į sveiką gyvenseną ir skaidrią būtí. İžymusis Vilhelmas Storosta-Vydūnas buvo sveikatos ir vidinès darnos propaguotojas, sveikos gyvensenos puoselètojas, siekęs lietuvių tautos žmones matyti sveikus ir taurius, kvietęs tausoti bei stiprinti sveikatą [1,2]. Istoriniame kontekste kaimyninèse Šiaurès šalyse danai orientavosi ị laimès suvokimą hygge ir lykke esmybèje, švedai akcentavo balanso svarbą gyvenime taikydami lagom sąvoką, o ištvermingi ir užsigrūdinę suomiai jau penkis šimtmečius garsėja savo sisu fenomenu [3-7].

Pastaruoju metu Lietuva ir kitos Baltijos šalys priskiriamos Šiaurès šalių regionui. Tad nestebina siekis atsigręžti ị artimiausių kaimynių ir tautų patirtí, tradicijas, nuostatas ir gyvenimo stilių, ieškant darnos sveikatos-gamtos-žmogaus dimensijose ir pritaikant tautinio tapatumo konstruktą mūsiškame kontekste. Nacionaliniai nekokybiško gyvenimo rodikliai skatina Baltijos šalis domètis artimiausių kaimynių - Šiaurès šalių istorine-kultūrine patirtimi, ideologiniu tapatumu. Ypač intriguojantis, imponuojantis sisu reiškinys, kaip suomiškos kultūros konstruktas. Analizuojant šį sudètingai apibrèžiamą ir apibūdinamą kultūrinį konstruktą kyla klausimų, ar tai ilgaamže tautos ideologija, gyvenimo stilius ar gyvensenos strategija? Giluminis šio reiškinio suvokimas igalina naujai pažvelgti į žmogaus-gamtos interakcijos galimybes, suvokti gyvensenos-sveikatos glaudumą ir darną. Straipsnyje analizuojama visuminès sveikatos ir darnos šiaurietiškos kultūros konstrukto struktūroje problema.

Tyrimo tikslas - atskleisti suomiškos kultūros fenomeno svarbą visuminei sveikatai ir darnai.

\section{Tyrimo medžiaga ir metodai}

Atliktas kokybinis tyrimas, taikyta hibridinè metodolo- 
gija. Naudota mokslinès literatūros analizè, diskurso analizè (sakytinis diskursas, pokalbio analizè), patirties analizè ir etnografinès strategijos elementai. Taikytas aprašomasis metodas, apibendrinimas, sisteminimas. Vyko individualūs pokalbiai bei apskritojo stalo diskusijos. Naudotos atmintinès, ir, anot J. Aleknavičienès ir kt. (2020), atmintinès yra tyrimo planavimo ir vykdymo dienoraštis, kuriame fiksuojamos pastabos, klausimai, idejos bei refleksijos, susijusios su atliekamu tyrimu [8]. Atmintinèse buvo užfiksuotos projekto dalyvių (mokslo bendruomenès, sveikatos ir medicinos bei socialinių mokslų atstovų, sveikatos ir saugos politiką formuojančių savivaldybių sektoriaus lyderių), turinčių ne tik kultūrinès ir gyvenimiškos etnografinès patirties, bet ir pagal savo kompetencijas gebančiu perteikti susistemintą informaciją iš mokslinių pozicijų, analizuoti tiriamą reiškinį, ižvalgos bei dalijimasis patirtimi. Mokslinès literatūros analizei naudotos mokslinès literatūros paieškos priemonès, tokios kaip PubMed duomenų bazè, informacijos pateikimo sistema Google Scholar, kompleksinè paieškos platforma ResearchGate ir kitos, socialiniai tinklai.

\section{Tyrimo rezultatai ir jų apibendrinimas}

Sveikatos harmonijos ir vidinės darnos siekiamybè. Lietuvos gyventojų dalyvavimas nuolatinèse socialinių-ekonominių reformų girnose, kurias lydejjo išorinių priežasčių mirtingumo pikai ir sinusoidès, blaškymasis tarp Rytų ir Vakarų, nesibaigiančios auksinio rojaus paieškos ir kloties skrydžiai aukštyn - žemyn neužtikrina visuminès sveikatos stabilumo ir darnos. „Lyderiavimas“ psichikos sveikatos sutrikimų struktūroje, aukštas savižudybių rodiklis, žemas jautrumo stresui slenkstis igalina fokusuotis tiek ị inovatyvių, tiek ị tradicinių prielaidų analizę ir paieškas.

Suirusi visapusiška sveikatos harmonija, išbalansuotos asmenybės proveržiai skatina tirti, stebèti, analizuoti priežastis bei formuoti ir telkti išteklius, stiprinti gebejjimus atkurti harmoniją. Didejjanti socialinè atskirtis (socialiniai netolygumai) didina vidinę įtampą, kelia stresą, išbalansuoja vidinę darną. Dalis šalies gyventojų susiduria su suvaržyta prieiga ir ribotu prieinamumu prie išteklių, kai iššūkiai dideli, bet realios galimybės ribotos.

Daugiau siekiamybių, galimybių, inovatyvių pasiūlymų, technologijų skatina civilizacijos pažangą, tačiau kartu didina ịtampą ir griauna vidinę harmoniją. Inovatyvumas bei technologizacija didina įtampą ir negatyviai veikia individo vidinį stabilumą. Daugumos šalies gyventojų, o ypač jaunų žmonių, gyvenimas glaudžiai susijęs su virtualia erdve. Intensyvus dalyvavimas socialiniuose tinkluose, įvairių prieigos priemoniu (apps, viber, whatsapp, messenger, skype ir pan.) ir sistemų vartosena didina psichologini stresą, verčia individą būti priklausomu nuo mobiliojo telefono, plan- šetės, nešiojamojo kompiuterio. Nuolatinis dalyvavimas neleidžia atitrūkti, išeiti iš darbinès terpès, skatina gyventi nuolat ịsitraukusiam ị veiklą (angl. always on). Darbo ir poilsio laikas niveliuojasi, persipina, išnyksta darbinès ir asmeninès veiklos, darbo ir poilsio laiko riba. Žmogus dirba darbo metu, grịžęs iš darbo, vakare, dalį nakties, savaitgaliais, per išeigines, poilsio dienas ir t.t. Padidinta rizika gresia dirbantiesiems nuotoliniu būdu, nes jų darbo ir poilsio laikas praranda savo ribas. Žmogus nebegali sustoti, daryti pertraukų, laikytis poilsio režimo, pasireiškia perdegimo sindromas (angl. burn out). Nenutrūkstama informacijos tėkmé, nuolatinis ịsipareigojimų, užduočių srautas, neatliktų darbų našta, kaltè atakuoja protines galias, vargina individą, sukelia nerimą, gilina stresą, provokuoja nuolatinę įtampą. Negatyviai veikia silpni gebejjimai neapsikrauti, atsisakyti priimti kiekvieną prašymą, pasiūlymą, užduotị ar darbą. I asmenį nukreipti lūkesčiai, nuolatinis vidinis ir išorinis spaudimas, stresas, negatyvizmas, nihilizmas, per dideli norai, siekiai, nerealios viltys išderina vidinę harmoniją. Totali technologiné visatos okupacija - technologijų paplitimas visose gyvenimo, veiklos srityse, nuolatinis, nenutrūkstamas idejų kūrimas ir jų pasiūla apkrauna mintis, viršija žmogaus energetines galimybes, veda prie emocinio sprogimo, perdegimo, pervargimo bei išsekimo.

Atsiranda subalansuotos, darnios psichikos sveikatos poreikis, svariu tampa tvarus tobulejimas, fizinès, emocinès, dvasinès bei psichikos sveikatos dermès siekis. Išsigrynina prioritetinis tikslas - subalansuotos, stabilios asmenybès kūrimas. Aktualizuojasi tinkamo gyvensenos modelio paieškos, laimès piliulių sintezavimas, siekis, kad gyvensena būtų sveika, saugi, tvari, darni, subalansuota ir tobula. Svarbios tampa idèjos bei pasiūlymai, kokie turètų būti siekiai, lūkesčiai, strategijos bei veiksmai, padedantys individui tapti sveikesniu ir harmoningesniu. Laikmetis ir intensyvejjantis gyvenimo sūkurys sudaro prielaidas mąstyti, ieškoti kelių ir galimybių, kaip išugdyti bei išsaugoti subalansuotą asmenybę. Svarbus tampa psichinès ir fizinès pusiausvyros lavinimas bei vystymas, remiantis kultūrinemis praktikomis. Baltijos šalys vis labiau domisi artimiausių kaimynių - Šiaurès šalių tautine patirtimi, šiaurietiškos kultūros konstruktais.

Šiaurietiškos kultūros konstruktas ir gyvensenos ypatumai: Suomijos pavyzdys. Mokslininkai, tyrinejję Šiaurès šalių kultūrinius ypatumus, išskirtinį dėmesị skyrè unikaliai suomiškai kultūrai ir gyvensenai bei originaliam sisu fenomenui [6,7,9-16]. Apžvelgiant Suomijos kultūrines realijas, pastebèta, kad suomiai pasižymi puikia savitvarda, susitelkimu, darbštumu, atsakingumu bei pareigingumu. Šios tautos gyventojai išsiskiria gebejimu išlikti ramiais ir išmintingais iškilus problemai, kliūtims ar netikètumams. Svarūs sprendimai priimami remiantis racionaliu protu, iš- 
vengiant impulsyvumo ar jausmingumo. Imponuoja jautrus suomių sąlytis ir ryšys su gamta [9-11], pirmenybès teikimas natūralumui, ekologiškumui, minimalizmui, subalansuotos asmenybès siekis. Aukšti šalies pasiekimai garsina šali edukologijos, technologijų, skaitmeninès sveikatos mokslų srityse, kartu su laimejjimais ir pažanga žmogaus gyvenimo kokybès, saugos, kultūros bei humanizmo kontekstuose. Pažymètina, kad Suomija pastaruoju metu buvo du kartus paskelbta laimingiausia šalimi pasaulyje (2018 m. ir 2019 m.), o remiantis socialiniais ir aplinkos rodikliais icvardinta pažangiausia (2016 m.), stabiliausia (2017 m.), saugiausia (2017 m.) ir laisviausia (kartu su Švedija ir Norvegija) planetos valstybe $[10,17,18]$.

Suomijoje nacionaliniu lygmeniu svarbus vaidmuo teikiamas lyčių lygybei užtikrinti. Tai vyksta jau 140 metų $[19,20]$. Suomiško tapatumo kontekste ženklus lygiavertiškumo komponentas, lyčių lygybės išlaikymas, vengiant tiek patriarchališko, tiek matriarchališko menkinimo, žeminimo, išnaudojimo apraiškų. Tai stebima pradedant nuo artimos aplinkos - šeimos, tarpusavio santykių lygmens iki pozityvių pavyzdžių nacionaliniu (valstybès valdymo, prezidentinio) lygiu. Suomių šeimose vyrauja darbų pasidalijimas, vyro ir moters pareigų pusiausvyra. Tévystės konstrukte svarbus laikas sau (angl. alone time), nes buvimas vienumoje sudaro galimybes autonomiškam laisvalaikiui, padeda pailsèti ir susigrąžinti jëgas, jaustis stipriu ir džiaugtis sau skirtu laiku. Suomių šeimos sutuoktinių kasdieniame gyvenime išryškeja trys domenai: šeimos gyvenimas, poros gyvenimas ir individo gyvenimas [21]. Pažymètina, kad individo gyvenimas, tiksliau asmeninis laikas yra skiriamas atokvėpiui, poilsiui, asmens darnos atkūrimui [21]. Suomių visuomenèje skatinama lyčių lygybė namuose. Kasdienio gyvenimo logistika gali būti varginanti, nežiūrint asmeninių santykių lygiateisiškumo. Tolygus veiklų ir darbų pasidalijimas, neatskleistų lūkesčių aptarimas, pagiriamasis bei paskatinamasis žodis mažina įtampą ir atveria sklandesnio bendravimo galimybes [9]. Vienodai vertinti vyro ir moters indèli namų aplinkoje suomiams yra itin svarbu.

Suomių kultūrinis savitumas atsiskleidžia per bendrus tautos požymius, savybes bei ypatumus. Suomiai - saugantys savo tautinị identitetą, prisirišę prie savo žemès, papročių ir ịpročių, tęsiantys iš ainių paveldètas tradicijas, aktyviai puoselëjantys šiaurietiškos gyvensenos ypatumus, nepaisant klimatinių sąlygų, daug laiko praleidžiantys lauke. Jie praktiški, daug dirbantys, aktyvūs, su būdinga gyvenimo nuostata „padaryk pats“ (angl. do-it-yourself, DIY) [11]. Namuose, buityje mieliau viską daro patys (pvz., tvarko namus), negu samdo pagalbos tarnybas. Jiems būdingas taupus vartojimas. Suomiai yra žiedinès ekonomikos ir tvaraus vartojimo atstovai - stengiasi sutaisyti senus, sulūžusius ar sugadintus daiktus, suteikti jiems naują gyvenimą, neskuba išmesti senų ir pirkti naujų daiktų. Nelinkę parduoti, bet mieliau renovuoja, remontuoja savo namus, yra dvasiškai artimai susiję su gimtine ir sentimentaliai brangiomis apylinkemis, vietove, kurioje gimè ir užaugo, gerbia tėvų ir protèvių žemę. Buvimas gamtoje, paprastų darbų atlikimas, buities tvarkymas, kasdienè fizinè veikla - svarbūs šiauriečiams. Manoma, kad pagarba kitiems bei gamtai, humaniškumas, santūrumas, sauga bei pasitikejjimas yra suomiškos laimès paslaptis.

Suomiai laiko save kukliais, santūriais, darbščiais, mąstančiais žmonėmis, kurie neatsitraukia ir niekada nepasiduoda [13]. Būti tokiais jiems padeda tradicinè suomių kultūrinè ideologija, vadinama originaliu žodžiu sisu.

\section{Suomiškas sisu fenomenas: aktualizacija ir praktinès ižvalgos}

Sisu fenomenas. Kas įkvepia Suomijos tautą, iš kur ji semiasi stiprybès ir vidinio kovingumo, kas yra tas magiškas žodis sisu, kodèl svarbūs sisu kultūrinio konstrukto tyrinèjimai? A. Duckworth savo pirmoje knygoje „Ištvermingumas: aistros ir atkaklumo galia" (angl. Grit: The Power of Passion and Perseverance) užsiminè apie 1940 metais Time žurnale publikuotą straipsni, kuriame buvo teigiama, kad suomiai turi kažką, ką jie vadina sisu. Tą mįslingaji sisu sudaro drąsa ir narsa, atkaklumas ir jëga, gebejimas kovoti, kovoti tvirtai trokštant laimèti [12]. Žodis sisu suomiams labai brangus [13]. E. Lahti (2014), tyrinejusi sisu, sieké ne tik apibendrinti ši kultūrinị konstruktą veiklos tyrimuose (angl. action research), bet ir pasidalinti rezultatais su globalia visuomene, siekiant perteikti šią gerają patirti kitoms tautoms, kitoms kultūroms [6]. Šiaurès šalies Suomijos kultūrinis konstruktas, žinomas kaip sisu, naudojamas apibūdinti enigmatinę galią, kuri padeda priimti nepakeliamus iššūkius, ivveikti neįveikiamas kliūtis, psichiškai ir fiziškai sudètingas situacijas. Tai tarsi veikimo mąstysena (angl. action mindset), nuoseklus ir drąsus požiūris ị iššūkius, kurie iš pirmo žvilgsnio atrodo viršijantys žmogaus galias ir pajègumus [6,7]. Suomiškas žodis sisu yra neišverčiamas. Apytiksliai tai reikštų valios, ryžto ir atkaklumo galią [13]. K. Pantzar (2018) sisu sieja su gerovès pojūčiu, nebrangiais, paprastais sprendimais, kuriems nereikia specialių programų, itaisų ar brangios įrangos, ir tai prieinama daugeliui žmonių, nepaisant laiko ar biudžeto apribojimų [10]. Sisu yra gebejjimas atlaikyti dideli stresą. Sisu remiasi suomiška dvasia, siekiu ryžtingai kovoti ir laimèti [22]. Šios šiaurietiškos būties esmè - imtis priemonių padidinti protinę ir fizinę gerovę, pagerinti savijautą, siekti sveikesnio ir laimingesnio gyvenimo. Sisu siekinys - iššūkius paversti galimybèmis [11].

Sisu yra 500 metų senumo suomių konstruktas, pasižymintis originalia dvasia ir stiprybe, leidžiančia žmonėms 
atkakliai išgyventi sunkumus, nepaisant jausmo, kad jie jau yra pasiekę savo fizinių ar protinių galimybių ribą. Sisu yra gebejjimas ištverti dideli stresą. Sisu yra tai, nuo ko žmogus priklauso, kai nieko nebelieka. Sisu suteikia žmogui paskutinị igalinimo postūmį, kai šis nesiryžta veikti [14]. Pagal šiaurietiško kultūrinio konstrukto ideologiją, sisu ugdymas tiek vyrams, tiek moterims yra vienodai svarbus [9].

Sisu - tai gebėjimas atsitiesti po pakartotinių nesèkmiu ir atkakliai tęsti užduotį bei siekti tikslo. Tai postūmis ne tik žengti pradinį žingsnį, bet ir skatinimas eiti pirmyn. Kokiomis akimirkomis prireikia griebtis savo sisu? Pavyzdžiui, esant už komforto zonos ribų (pvz., kai liko 6 mylios maratonui baigti, bet jaučiate, kad apleidžia jègos; jaučiate, kad padarete viską, ką galite, kad pasiektumète tikslą, tačiau jo dar nepasiekète; kai ruošiatès kelti sunkesnį svorị nei tas, kuri anksčiau kèlète; kai ilgas pasipriešinimo ir ištvermès išbandymas, atrodo, niekada nesibaigs) [6,14]. Suomė Emilia Lahti sistematiškai aprašè sisu kaip žmogaus viduje slypinčios universalios latentinès energijos fenomeną. Pagrindiniuose jos tyrimų rezultatuose atsiskleidè sisu kaip galios rezervo suvokimas, leidžiantis nepaprastiems veiksmams ivveikti psichiškai ar fiziškai sudètingas situacijas [6,7]. Daugybę kartų gyvenime žmonès susiduria su iššūkiais, kuriuos turi priimti drąsiai ir ryžtingai. Daugeliui tokiose situacijose pasireiškia begalinis pasipriešinimas, atsiranda baimè, kaip tai ištverti. Susidūrus su akimirkomis, kuriose jaučiamasi pasiekus savo galimybių pabaigą ir matant tik begalinį drąsos ir atkaklumo eiti pirmyn poreiki, prireikia ypatingos vidinès stiprybès išgyventi ir įveikti ši iššūkị [14].

Ar tai tik suomiu galimybè? Ar gali kiekvienas išsiugdyti atsparų suomišką stilių? Rasti savo sisu? [11]. Suomijai kaip sisu iniciatorei gali priklausyti pradinis sisu kaip kultūrinio konstrukto monopolis. Tai universali galia, kurios potencialą turi visi individai. Sisu padeda suvokti žmogaus atsparumo determinantes - atsparumą lemiančius veiksmus, ir suprasti, kaip stiprinti atsparumą, taikant sisu [6].

Sisu įkvepia atkakliai siekti tikslų, kovoti dèl sèkmès, nepaisant sunkumų, net kai atrodo, kad jau yra pasiektos žmogiškuju galių ribos. Atkaklumas (angl. perseverance), ištvermè (angl. stamina), tvirtumas (angl. steadfastness), tamprumas, gebejjimas greitai atgauti jègas, pozityvus mąstymas, energijos kaupimas - yra glaudžiai susiję su sisu reiškiniu $[6,7,10,11]$.

Sisu neturi nieko bendro su altruizmu, humaniškumu ar pagalba. Pertekliniai veiksmai, perteklinè veikla - nesusiję su sisu. Sisu esmè - išlikti (angl. to survive). Sisu esmybės išraiška praktiniame kontekste - tai maudynès šaltame vandenyje, saunos galia, gamtos terapija, laimès siekis, judejjimas sveikatai stiprinti, sveikas maistas, šiaurietiškas minimalizmas, fizinès ir protinès veiklos dermè. Ugdyti ir rasti savo sisu - iššūkis individui, o kartu ir visuminès sveikatos, darnos ir pilnatvès prielaida.

Sisu ugdymas: praktinès įžvalgos. Manoma, kad sisu yra lanksti kokybè, ir sisu galima sąmoningai lavinti. Dauguma sisu tyrimuose dalyvavusių respondentų teigé, kad jie suinteresuoti ugdyti ir plètoti ši gebejjimą [6,7]. Sisu ugdymas, atsarginès, papildomos energijos kaupimas, atkaklumo, valios, darnos stiprinimas sietini su tokiais komponentais, kaip saveika su gamta, gamtos bei miško terapija; pozityvumas; poilsis ir rekreacija; atsiribojimas ir atsitrankimas; naštos sumažinimas (fragmentizacija); išejjimas iš komforto zonos (maži iššukiai); perdavimas ir plitimas; fizine veikla, fizinis aktyvumas; apdovanojimas, ịveikus užduotị.

Saveika su gamta, gamtos bei miško terapija (angl. nature therapy, forest therapy). Atotrūkis nuo gamtos bei natūralumo ir posūkis ị sintetinị gyvenimą suarde žmogaus simbiozę su natūralia visata, pasmerkdamas jị nuolatinès ịtampos, streso, baimių ir nesaugumo būklei. Gamtos poveikis suteikia žmogui daugybę pozityvių efektų. Gamta mažina stresą, leidžia ilsètis, ,išvalyti“ mintis, būti savimi.

Sakoma, kad pati ramiausia vieta pasaulyje yra Suomijos miškas. Ganètinai saugi Suomijos gamta yra garsi sielą raminančia tyluma. Gamta yra didingas variklis, padedantis auginti suomiškajj sisu [9]. Sąlytis su gamta $[10,11]$ yra svarbus žmogui, jo dvasiai, sveikatai ir darnai. Tai, kas šiandien vadinama gamtos terapija, miško terapija, suomiams buvo ir yra natūralus, igimtas patyrimas. Atsigręžimas i gamtą teikia mintims ramybę, ramina sielą ir ịkvepia naujiems iššūkiams. Gamta - tai atokvèpis mąstymui, galimybe pabūti tyloje, poilsis mintims.

Suomiai rekomenduoja ilsètis gamtoje ir ją stebèti. Pvz., susirasti gamtoje vaizdingą vietą ir tyloje stebèti aplinką. Stebėti skrendantị lapą, paukští, drugelị, debesèlị, augančius grybus, pajusti vejjo dvelksmą veide. Užmerkti akis ir ikvėpti, stengiantis susieti kvapus su jausmais ir prisiminimais. Susiradus medị, prie kurio norètųsi priglusti ir pailsèti, paliesti jị ir pajusti ryši su gamta ir augalija. Pabandyti prisiglausti prie medžio užmerktomis akimis ir paklausti savęs - ką jaučiu [9].

Pozityvumas. Pozityvumas yra svarbus ir galingas. Analizuojant poveikị, kurị daro komplimentas, pastebèta, kad komplimentas priverčia žmogų išsitiesti, šypsotis, elgtis kitaip. Pozityvumas akivaizdžiai pakylẻja. Pozityvumas ,nustato bendrą gyvenimo sistemose toną“" [23]. Pozityvus mąstymas igalina nepasiduoti, ,nenuleisti rankų“ [7]. Teigiamą požiūrị galima sąmoningai ugdyti. Dispozicinis optimizmas, t.y. tikejjimas, kad nutiks gerų dalykų, gali mažinti vienišumo jausmą bei didinti toleranciją skausmui. Pozityvumas yra pagrindinis kūrybiškumo komponentas ir tiek nuolatinè laimé, tiek trumpalaikès malonumo akimirkos padeda geriau 
„išspręsti ịžvalgos dèliones“. Gera nuotaika padeda atsipalaiduoti, o atsipalaidavus smegenys pasirengia užmegzti pozityvius ryšius [23]. Pozityvi adaptacija, pozityvūs, ,prikeliantys gyvenimui“" pokyčiai individo gyvenime, pozityvi kokybė yra glaudžiai susiję su sisu ir sėkmès pavyzdžiais suomių istorijoje [7]. Pozityvumas daro ịtaką ne tik pačiam individui, bet ir aplinkiniams žmonèms bei sistemoms, su kuriomis jis bendrauja. Visi gali būti pozityvūs. Moksliniai tyrimai rodo, kad galima išmokti priimti reikiamą mąstyseną. Strateginis optimizmas (nepainiojant jo su per dideliu pasitikejjimu) gali padèti susitvarkyti gyvenimą, tikèti, kad viskas išsispręs, o problemos nesužlugdys asmens gyvenimo [23].

Sisu - tai požiūris, skatinantis pozityvius veiksmus, inspiruojantis ịprastines jeggas išaugti ir išsiveržti iš savo ribų. Tuo sisu parodo jo akivaizdžią vietą pozityviojoje psichologijoje („moksle apie laimę") [9]. Savigrauža, savęs alinimas negatyviomis mintimis, pozityvumo stoka nukreipia ir „stumia“ individą ị depresiją, liūdesị, neviltį, beviltiškumą. Negatyvios mintys, kaip teigia K. Pantzar (2018), „traukia žemyn kaip sūkurys" [10]. Bendravimas su pozityviu žmogumi, pozityvi veikla, pozityvus požiūris bei mąstymas (nenukrypstant ị infantiliškumą), pozityvus susitikimas, pokalbis, skambutis ar laiškas ịkvepia pozityviam gyvenimui, darbingumui, kūrybiškumui. Pozityvumas bei emocinès sveikatos stiprinimas yra svarbūs ugdant sisu.

Poilsis (individo poilsis) ir rekreacija. Darbo ir poilsio dermè, individo poilsis, rekreacija, subalansuotas dienos režimas yra svarbūs ugdant sisu. Darbo ir poilsio kaita yra būtina, nes nepertraukiamas darbas nualina ir sunaikina protą, sielą ir kūną. Paprasta suomiška formulè -8 valandos darbo, 8 valandos poilsio (laisvalaikio) ir 8 valandos miego padeda išlikti subalansuota, kūrybinga, atsparia gyvenimo iššūkiams asmenybe.

Nuolatiniai trukdžiai, pasyvi gyvensena, laikysenos ir regos problemos verčia suomius tausoti savo proteviškas šaknis ir gebèti atsiriboti nuo nesibaigiančių darbų ir užduočių. Tradicinès išvykos savaitgaliais ị užmiestį, i gamtą igalina atitrūkti nuo darbo ir pailsèti.

Suomiai mano, kad būtina skirti laiko buvimui vienumoje. Patariama kasdien rasti laiko prisèsti nuošaliau nuo kitų dvidešimčiai minučių (ar bent penkioms) ir nieko nedarant, tiesiog kvépuojant, pasėdèti užmerktomis akimis. Taip pabūti su savimi ir pamąstyti - kas vyksta, ką jaučiu. Taip susikoncentruoti ị save ir atverti kelią vidinei stiprybei - savo sisu [9]. Individo poilsis papildo jègas, grąžina energiją, ugdo tvirtumą ir atkaklumą.

Atsiribojimas ir atsitraukimas. Sisu ideologijoje svarbus atsiribojimas nuo veiksnių ir įvykių, kurių negalima pakeisti (pvz., liga, mirtis, negalia). Susitaikymas su neišvengiamumu, prièmimas reiškinių, kuriems negali daryti įtakos, stiprina asmenybę, ugdo atsparumą ir pusiausvyrą. Be to, svarbus yra ir atsiribojimas „nuo to, kas ne tavo“ - nuo svetimų vaidmenų, užduočių, pareigų, atsakomybès. Asmuo negali gyventi kitų žmonių gyvenimo, sirgti kitų ligomis, atlikti visų užduotis. Atsiribojimas nuo svetimų problemų didina stabilumą, grūdina sielą, ugdo savitvardą ir stiprina dvasią. Tai leidžia taupyti energiją, pajègumus, saugoti emocinę sveikatą, susitelkti tikslų ir rezultatų siekiui.

Sisu ugdymui yra svarbus gebėjimas atsitraukti. Atsitraukimas būtinas jëgų taupymo veiksnys. Perteklinès kovos yra nereikalingos ir žalingos. Kiekvienas mūšis neturi būti beprasmis, ypač, jeigu jègos jam nugalèti yra nepakankamos. Protingas atsitraukimas yra svarbiau, negu nereikalingas jègų eikvojimas. Konstruktyvus sisu yra ne aklas ir obsesinis, bet lankstus, adaptyvus ir susietas su priežastimi [7]. Yra situacijų, kai, užuot kovojus, verčiau priimti situaciją, susitaikyti su ja ir kartais pasitenkinti tuo, ką turi [7]. Kai kuriose situacijose sisu ugdymui yra svarbus lankstumas (angl. flexibility).

Naštos sumažinimas (fragmentizacija). Naštos sumažinimas, suskaldymas ị mažesnius fragmentus arba fragmentizacija sisu ideologijoje iggalina paprasčiau siekti norimo tikslo. Sumažinus milžinišką iššūkị ir jị suskaidant ị mažesnes užduotis, palengvejja nuoseklus norimo rezultato siekimas. Sisu yra susijęs su problemų, diskomforto ir iššūkių ịveikimu. Sisu fenomenas pabrèžia intensyvų trumpalaikių užduočiu atlikimą, o ne ilgalaikị siekinị bei susitelkimą ties dideliais, visaapimančiais gyvenimo tikslais [7]. Žingsnis po žingsnio paeiliui atliekant mažesnes užduotis, prieinama prie galutinio siekiamo taško. Anot E. Lahti (2014), atkaklumas siekiant ilgalaikio tikslo, gali būti traktuojamas kaip fiksuota kokybè. Sisu konstruktas yra lanksti kokybè, kurią pasitelkus tikslas yra suskaidomas ir jo siekiama lanksčiai - dalimis (fragmentais) [6].

Išejjimas iš komforto zonos (maži iššūkiai). Nedideli iššūkiai (išèjimas iš komforto zonos) gyvenime yra reikalingi. Maži iššūkiai ugdo kūrybingumą, paverčia gyvenimą dinamišku, skatina tobulèti, ieškoti sprendimo, veikti, judèti, eiti pirmyn. Komforto zonos yra naudingos, tačiau, norint augti ir tobulèti, reikia iššūkių. Komforto zona - tai psichinè būsena, kurioje prioritetizuojamas individo egzistavimas. Tai aplinka, kurioje žmonès paprastai leidžia savo kasdienybę, darydami dalykus, kuriuos geriausiai moka atlikti. Kai individas priima iššūkius ir aktyvuoja savo sisu, jis gali pasiekti nuostabiu rezultatų. Priimant pernelyg sudètingus iššūkius, gali būti sukeliamas per aukštas streso lygis, todèl nerimas, atejęs su iššūkiu, turi būti kontroliuojamo lygmens [9]. Saikingais iššūkiais galètų tapti naujos vietovès aplankymas, naujo pomėgio išbandymas, neịprastos ar sudėtingesnès užduoties atlikimas. Iššūkiu galètų būti ir pastangos išmokti naujų 
dalykų (tiek profesinëje veikloje, tiek laisvalaikio aplinkoje).

Perdavimas ir plitimas. Sisu fenomenui būdingas ideologinis transformavimas, gyvensenos stiliaus perdavimas, plitimas (angl. spreading), sklidimas, spinduliavimas (angl. radiation). Sisu patyrimas perduodamas iš kartos ị kartą (angl. generation - to - generation). Be to, žinios apie sisu transformavimas vyksta ir horizontaliuoju plitimu (angl. horizontal spreading) visuomenèje. Žinia apie sisu turi sklisti, ikvėpti naujus šeimos narius, bendruomeniškai sujungti giminaičius, paskatinti juos siekti stiprybès susitelkti ypatingam veiksmui. Sukaupti perteklines jëgas, surasti savyje neịprastinès stiprybès, ugdyti vidinę darną, susitelkimą ir harmoniją tėvai ir senoliai moko savo atžalas gyvu pavyzdžiu, pasakojimais ir paskatinimu. Tévai vaikams yra pavyzdžių, vaidmenų modeliai (angl. role models). Kaip nugalèti, įveikti iššūkius vaikai išmoksta iš tèvų, iš šeimos narių. Tẻvai paskatina vaikus siekti tikslų, juos padrąsina, palaiko, padeda šiems suformuoti nuostatas. Panašus vaidmuo tenka ir mokytojams, tačiau šeimos pavyzdys yra prioritetinis. Sisu gali tapti iššūkiu tėvams, jeigu jie stengiasi palengvinti vaikams užduotis ir atima iš vaikų galimybę pasimokyti iš sunkumų ir iššūkių. Sisu yra kultūrinis paveldas, kuris plinta visuomeneje. Sisu atsiranda visuomeneje ir toliau spinduliuojamas ị visuomenę.

Fizinè veikla ir fizinis aktyvumas. Judèjimas ir fiziniai pratimai padeda stiprinti sveikatą ir ištvermę, o tai didina sisu [10]. Suomių mokslininkai konstatuoja, kad geriausi žmogaus būties aspektai yra tai, kad žmogus gali mąstyti ir judèti [24]. Fiziniai pratimai sumažina stresą ir depresiją. Per didelis stresas didina mirtingumą nuo širdies ir kraujagyslių ligų bei psichikos sveikatos sutrikimų riziką. Fiziniai pratimai sustiprina galvos smegenų ląstelių veiklą. Fizinio aktyvumo poveikyje padidèja nervinių ląstelių šakos ir pagerẻja atmintis [24]. Fizinè veikla didina atsparumą, užgrūdina, padeda kaupti vidinę energiją.

Apdovanojimas, ịveikus užduotị. Ar būtina padèkoti sau, apdovanoti save, ịveikus užduotį? Viena vertus, sėkmingas tikslo pasiekimas jau savaime yra didžiausias atlygis. Atlikto darbo, pasiekto rezultato, pergalès džiaugsmas yra savaiminis atpildas už įdètas pastangas. Kita vertus, ịveikus sunkumus ir ịvykdžius užduotị, galima save apdovanoti. Tai gali būti laikas daryti tai, ką mėgsti. Savaitgalis su šeima, su vaikais, laisvalaikis su draugais, laikas, praleistas su augintiniais, pasivaikščiojimas miške ar prie jūros. Specialus prizas vaikui taip pat gali būti atpildas už pastangas ir įtemptą darbą.

\section{Išvados}

Lietuvai ir kitoms Baltijos šalims aktuali artimiausių kaimynių - Šiaurès šalių originali kultūrinè patirtis, nuostatos, gyvenimo stilius, ieškant darnos sveikatos-gamtos-žmogaus dimensijose. Straipsnyje analizuojamas šiaurietiškas kultūrinis konstruktas sisu, jo sąlytis su visumine sveikata ir harmonija. Tai suomių kultūros fenomenas, originalios gyvensenos pavyzdys, tradicinės ideologijos konceptas. Sisu - nuoseklus ir drąsus požiūris ị iššūkius, kurie, iš pirmo žvilgsnio, atrodo viršijantys žmogaus galias ir pajègumus. Tai energijos rezervas, skirtas iššūkiams nugalèti, savita drąsa ir atkaklumas, papildomų jègų sutelkimas ir pasireiškimas, siekiant užsibrèžto tikslo. Sisu padeda didinti atsparumą, atkaklumą, ištvermę bei stiprinti visapusišką sveikatą ir darną. Pastangos sukaupti papildomą atsarginę energiją, išsiugdyti, surasti savo sisu ir taip sustiprinti savo fizinę ir psichikos sveikatą bei harmonizuoti visuminę žmogaus sveikatą yra siektinas iššūkis individui ir visuomenei. Konstruktyviam sisu ugdymui svarbūs komponentai yra sąveika su gamta, gamtos bei miško terapija, pozityvumas, poilsis ir rekreacija, atsiribojimas ir atsitraukimas, naštos sumažinimas (fragmentizacija), išejimas iš komforto zonos (maži iššūkiai), perdavimas ir plitimas, fizinè veikla bei fizinis aktyvumas, apdovanojimas, ịveikus užduotị.

\section{Padèka}

Nuoširdžiai dèkojame už geranorišką pagalbą, îkvėpimą, įžvalgas ir vertingas diskusijas kolegoms ir draugams Suomijoje, o ypač prof. Seppo Meri, prof. Tarja Suominen, p.Yrjö Heimonen, doc. Minna Koskimäki ir doc. Jari Kylmä.

\section{Literatūra}

1. Vydūnas. Sveikata, jaunumas, grožè. Tilžè, 1928.

2. Vydūnas. Raštai. Vilnius: Mintis, 1991;2.

3. Wiking M. The little book of Hygge: Danish secrets to happy living. The Happiness Research Institute, Copenhagen. New York: HarperCollins Publishers 2017.

4. Wiking M. The little book of Lykke: The Danish search for the world's happiest people. London: Octopus Publishing Ltd 2017.

5. Dunne L. Lagom: The Swedish art of balanced living. London: Octopus Publishing Ltd, 2017.

6. Lahti E. Above and beyond perseverance: An exploration of Sisu. Doctoral dissertation. Philadelphia: University of Pennsylvania 2014.

7. Lahti E. Embodied fortitude: An introduction to the Finnish construct of sisu. International Journal of Wellbeing 2019; 9(1):61-82.

https://doi.org/10.5502/ijw.v9i1.672

8. Aleknavičienė J, Pocienė A, Šupa M. Kaip parašyti mokslinị rašto darbą? Vilnius: Vilniaus universiteto leidykla, 2020.

9. Nylund J. Sisu: The Finnish art of courage. London: Gaia, Octopus Publishing Group Ltd 2018.

10. Pantzar K. Finding sisu: In search of courage, strength and happiness the Finnish way. London: Hodder\& Stoughton Ltd 2018.

11. Pantzar K. The Finnish way: Finding courage, wellness, and 
happiness through the power of sisu. New York: TarcherPerigee 2018.

12. Duckworth A. Grit: The power of passion and perseverance. New York, NY: Scribner, 2016.

13. Sinkkonen J. The land of sauna, sisu and Sibelius - an attempt at a psychological portrait of Finland. International Journal of Applied Psychoanalytic Studies 2013;10(1): 49-52. https://doi.org/10.1002/aps.1340

14. Velázquez M. Sisu: Beyond perseverance. 2014. https://positivepsychologynews.com/news/marta-velazquez/2014121530618

15. Amato-Henderson S, Slade D, Kemppainen A. Measuring Sisu: Development of a tool to measure mental toughness in academia. Proceedings of the Human Factors and Ergonomics Society Annual Meeting 2014;58(1):1434-1436.

https://doi.org/10.1177/1541931214581299

16. Taramaa R. Stubborn and silent Finns with "sisu" in FinnishAmerican literature: An imagological study of Finnishness in the literary production of Finnish-American authors. Oulu: Oulu University Press 2007.

17. Helliwell JF, Layard R, Sachs JD (eds.). World happiness report 2019. New York: Sustainable Development Solutions Network 2018.

18. Helliwell JF, Layard R, Sachs JD (eds.). World happiness report 2019. New York: Sustainable Development Solutions Network, 2019.

19. Finland is a gender equality pioneer. Ministry of Social Affairs and Health, Helsinki, Finland 2020.

https://stm.fi/en/finland-is-a-gender-equality-pioneer

20. Gender equality is a core value in Finland. Ministry of Social Affairs and Health, Helsinki, Finland 2020. https://stm.fi/ en/140-years-of-gender-equality

21. Böök ML, Mykkänen J. Finnish mothers' and fathers' constructions of and emotions in their daily lives. Scandinavian Journal of Educational Research 2019;63(3):412-426. https://doi.org/10.1080/00313831.2017.1376351

22. Cohen JV. Sisu - the ability to keep fighting after most would quit. JAMA Oncology 2018;4(10):1329.

https://doi.org/10.1001/jamaoncol.2018.1571

23. Hämäläinen RP, Jones R, Saarinen E. Being better better: Living with systems intelligence. Helsinki: Aalto University Publi- cations, Nord Print,2014. http://sal.aalto.fi/publications/pdf-files/being_better_better_living_with_systems_intelligence.pdf

24. Meri S. Lenkille ja lukemaan! Lääketieteellinen Aikakauskirja Duodecim, 2019;135(5): 419.

https://www.duodecimlehti.fi/lehti/2019/5/duo14811

\section{COMPREHENSIVE HEALTH AND HARMONY IN NORDIC CULTURAL CONSTRUCT \\ B. Strukčinskienė, S. Griškonis}

Keywords: comprehensive health, harmony, cultural construct, Nordic concept, Finland, sisu phenomenon.

Summary

Today Lithuania and other Baltic countries belong to the Nordic Region. It is therefore not surprising that there is a desire to look at the experiences, traditions, attitudes, and lifestyles of closest neighbours and nations, for seeking harmony in the health-nature-human dimensions, and for adapting the construct of national identity to our context.

The article discusses the Nordic cultural construct sisu in the context of its relation to comprehensive health and harmony. It is a phenomenon of Finnish culture, an example of original lifestyle, a concept of traditional ideology. Sisu is a consistent and courageous approach to challenges that seem to exceed human powers and capabilities. It is an energy reserve designed to overcome challenges. The paper analyses the components of Finnish cultural identity, discusses how to educate constructive sisu, and how it contributes to building resilience, perseverance, grid, and to comprehensive health and harmony promotion.

The efforts to accumulate additional reserve of energy, to develop, to find $s i s u$, and thus to strengthen physical and mental health and to harmonize the comprehensive human health is an achievable challenge for the individual and society.

Important components for developing sisu are: interaction with nature, nature therapy, forest therapy; positivity; relaxation and recreation; dissociation and stepping back; reduction of burden (fragmentation); leaving the comfort zone (small challenges); spreading and radiation; physical activity; and reward for completing a task.

Correspondence to: birutedoctor@gmail.com

Gauta 2020-12-01 